\title{
BRASÍLIA: LEGISLAÇÃO PATRIMONIAL E GESTÃO URBANA*
}

Sylvia Ficher

\section{Resumo}

Discutir a gestão da área tombada do Distrito Federal exige a análise de suas principais normas de proteção em vigor. A começar pelo Decreto no 10.829/1987, baixado para garantir a inclusão de Brasília no Patrimônio Cultural da Humanidade da UNESCO; abarcando insensata área de mais de cem quilômetros quadrados, estabeleceu uma sistemática original de proteção urbana, por meio do controle das quatro escalas do Plano Piloto - monumental, gregária, residencial e bucólica. O tombamento federal veio com a Portaria no 4/1990 do Instituto do Patrimônio Histórico e Artístico Nacional (IPHAN), então Instituto Brasileiro do Patrimônio Cultural (IBPC), alterada pela Portaria no 314/1992. A diferença entre elas é mínima e bastante controversa: o acréscimo de um parágrafo que garantiu a Oscar Niemeyer o direito de projetar um edifício em área non-edificandi do Eixo Monumental. Um quarto de século depois, em menos de dois meses foram divulgadas duas novas normas. Pelo IPHAN foi publicada a Portaria no 68/2012, abrangendo a envoltória do perímetro tombado e abarcando uma área com cerca de setecentos quilômetros quadrados. $\mathrm{Ou}$ seja, essa portaria nos reconduzia aos primórdios de Brasília, reiterando o cordão sanitário imposto ao Plano Piloto ainda antes de sua inauguração, quando da criação de Taguatinga em 1958. Pela Secretaria de Desenvolvimento Urbano e Habitação (SEDHAB) foi apresentada minuta do Plano de Preservação do Conjunto Urbanístico de Brasília (PPCUB). Norma bem mais complexa que as anteriores, contém 178 artigos, preconizando o esquartejamento definitivo do território. Felizmente, em 2016 o IPHAN aprovou uma regra bem mais eficiente, a Portaria no 166/2016, a qual busca superar, pelo estabelecimento de duas macrozonas, as dificuldades de gestão advindas de um território demasiado dilatado e da inclusão de bairros que não deveriam sequer estar sujeitos a medidas de proteção, alguns não completamente edificados até hoje. A Macrozona B serve como área de amortecimento da Macrozona $\mathrm{A}$, a qual contém aquela porção do Plano Piloto real que mais se aproxima do Plano Piloto idealizado. Em vigor, recebeu alterações pontuais pela Portaria no 421/2018. Porém, a tendência predominante ainda é conceber a preservação do Plano Piloto no vácuo. Apenas uma política que fortaleça os elos entre esse core de alto significado urbanístico e arquitetônico e a metrópole brasiliense poderá desviar as pressões imobiliárias que sobre ele são exercidas para a aglomeração maior, esta sim necessitando urgente qualificação. Quanto mais elevada a urbanidade do entorno do Plano Piloto, mais garantida estará sua salvaguarda.

Palavras-chave: Brasília, Plano Piloto, GDF, UNESCO, IPHAN, tombamento.

* Trabalho apresentado no $3^{\circ} \mathrm{Sim}-$ pósio Científico do ICOMOS/ Brasil, 2019. 


\section{Abstract}

To discuss the management of the Federal District area classified as landmark requires the analysis of the main protection regulations in force. Beginning with Decree N. $10.829 / 1987$, established to ensure the inclusion of Brasilia in the UNESCO World Cultural Heritage; encompassing a senseless area of more than a hundred square kilometers, it set up an original system of urban protection, through the control of the Pilot Plan's four scales-monumental, gregarious, residential and bucolic. The Federal listing came with Ordinance N. 4/1990 of the National Institute of Historical and Artistic Heritage (IPHAN), then Brazilian Institute of Cultural Heritage (IBPC), amended by Ordinance N. 314/1992. The difference between them is minimal and quite controversial: the addition of a paragraph that guaranteed Oscar Niemeyer's right to design a building in the non-adificandi area of the Monumental Axis. A quarter of a century later, in less than two months, two new norms were released. By IPHAN it was published Ordinance N. 68/2012, concerning the periphery of the listed perimeter and covering an area with some seven hundred square kilometers. In other words, this ordinance brought us back to the beginnings of Brasilia, reiterating the cordon sanitaire imposed on the Pilot Plan even before its inauguration, with the creation in 1958 of a satellite town, Taguatinga. The Federal District Government presented the draft for a Plan for Brasilia's Urban Preservation (PPCUB). A extensive rule, it contains 178 articles, enforcing the definitive quartering of the territory. Fortunately, in 2016 IPHAN approved a much more efficient rule, Ordinance No. $166 / 2016$, which seeks to overcome, through the establishment of two macrozones, the management difficulties arising from a territory that is too large and from the inclusion of neighborhoods that should not even be subject to measures of protection, some not completely built up today. Macrozone B serves as a buffer zone for Macrozone A, which contains that portion of the actual Pilot Plan that most closely matches the idealized Pilot Plan. In force, it has received $a d$ hoc amendments by Ordinance No. 421/2018. However, the predominant tendency is still to conceive the preservation of the Pilot Plan in a void. Only a policy that strengthens the links between this core of outstanding urban and architectural significance and the metropolis can divert real estate pressures that are exerted on it to the larger agglomeration, which in fact needs urgent qualification. The higher the urbanity surrounding the Pilot Plan, the more guaranteed will be its safeguard.

Keywords: Brasília, Pilot Plan, Federal District Government, UNESCO, IPHAN, listing. 
Muito se fala do descaso da população brasiliense para com a preservação do $\mathrm{Pla}$ no Piloto, do seu desrespeito às características marcantes da cidade concebida por Lucio Costa. $\mathrm{O}$ cidadão brasiliense é acusado de tudo: é ele que invade, é ele que gradeia, é ele que cerca, é ele que estica e puxa; ele que polui visualmente a cidade... Contudo, se considerarmos a administração urbana do Distrito Federal, seja do território sob proteção - o Plano Piloto e suas adjacências -, seja do conjunto maior da metrópole, constata-se que suas ações são, em geral, não apenas insuficientes, como muitas vezes equivocadas.
Voltemos o olhar para aqueles espaços que não foram maltratados pelos mal-educados brasilienses. Examinamos os espaços públicos que não sofreram nenhuma ocupação ilegal, que não foram nem gradeados e nem invadidos, e nos deparamos com o quê? Com áreas verdes descuidadas, que não recebem um mínimo tratamento paisagístico, que não oferecem quaisquer equipamentos, nem mesmo calçadas ou bancos de praça. Não passam de terrenos baldios...

Muito se fala também sobre uma maior integração do Plano Piloto com o restante da aglomeração, uma maior

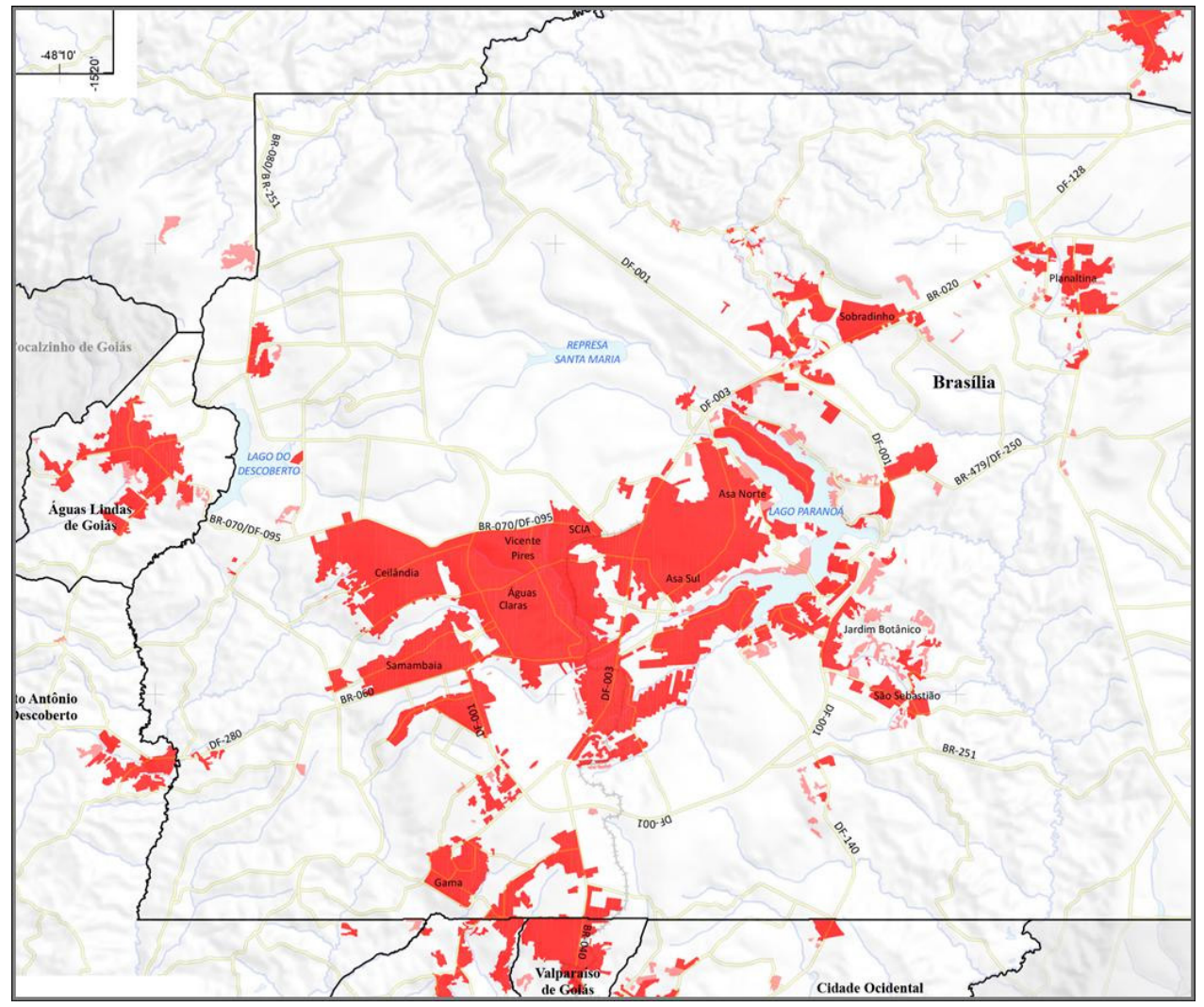

Figura 1 - Região Metropolitana de Brasília. Fonte: IBGE, Coordenação de Geografia, Áreas urbanizadas do Brasil: 2015, 2017. Mapa 23; disponível em: <https://www. ibge.gov.br/apps/areas_urbanizadas/>. Acesso: 18 fev. 2019. 
integração entre os diferentes bairros da metrópole brasiliense insensatamente dispersos pelo Distrito Federal e seu entorno. Contudo, os instrumentos legais propostos para a sua gestão patrimonial em ambas as esferas do poder público, distrital e federal, contam uma história muito diferente.

\section{QUAIS SÃO ESSES INSTRUMENTOS?}

Há trinta anos está em vigor o Decreto $\mathrm{n}^{\circ} 10.829$, de 14 de outubro de 1987, do Governo do Distrito Federal, que pretende cuidar da "preservação da concepção urbanística de Brasília” por meio de meros dezesseis artigos. Pensado levando em consideração tão somente o Plano Piloto e baixado sob medida para garantir a inclusão da cidade no Patrimônio Cultural da Humanidade da UNESCO - confirmada a 7 de dezembro daquele ano -, esse decreto estabeleceu uma sistemática diferenciada, por meio do controle das quatro escalas que seriam apanágio do Plano Piloto - monumental, gregária, residencial e bucólica. De modo que o tombamento não incide nas edificações em si, à exceção daquelas sujeitas a legislações próprias de proteção.

Estabeleceu também uma área tombada de excessiva extensão, que em muito extravasa o Plano Piloto, em contrate com as expectativas de seu urbanista. No texto Brasilia revisitada (1987), Lucio Costa havia proposto que o tombamento se restringisse "ao conjunto urbanístico-arquitetônico da Praça dos Três Poderes, incluindo-se os palácios do Itamarati e da Justiça". De resto, as suas recomendações para o Plano Piloto foram: manutenção dos gabaritos ao longo do Eixo Monumental e do Eixo Rodoviário; consolidação das superquadras e unidades de vizinhança conforme a proposta original; revisão dos setores centrais, para abrandar a excessiva setorização e melhorar os percursos de pedestres e a circulação de veículos.

O tombamento federal viria pelo Instituto do Patrimônio Histórico e Artístico Nacional (IPHAN), então denominado Instituto Brasileiro do Patrimônio Cultural (IBPC), com a Portaria no 4, de 14 de março de 1990, alterada pela Portaria $n^{\circ} 314$, de 8 de outubro de 1992, hoje em vigor. Ambas abrangem a mesma área e repetem em grande parte o decreto distrital, porém graças a uma admirável capacidade de síntese, reduzidas a apenas treze artigos.

A diferença entre as duas portarias federais é mínima, porém significativa. Ela ilustra bem as dificuldades para a implementação de ações de preservação no caso do Plano Piloto. Bastante controversa, uma única alteração foi introduzida no intuito de garantir a Oscar Niemeyer o direito de projetar um edifício no canteiro central do Eixo Monumental, legalmente definido como área non-edificandi. A manobra se deu pelo acréscimo de um terceiro parágrafo ao Art. $9^{\circ}$ da portaria de 1990, segundo o qual,

excepcionalmente, e como disposição naturalmente temporária, serão 

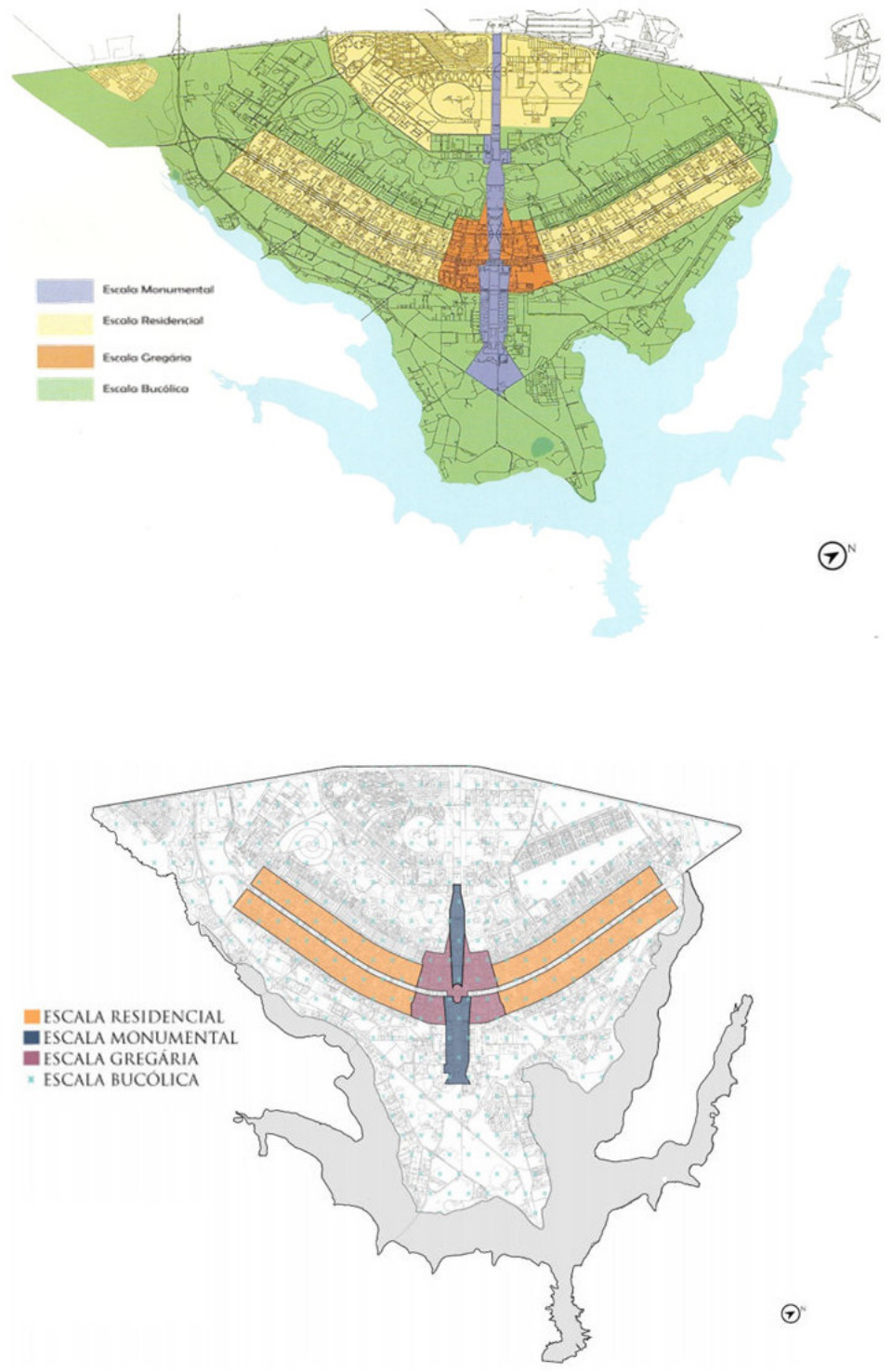

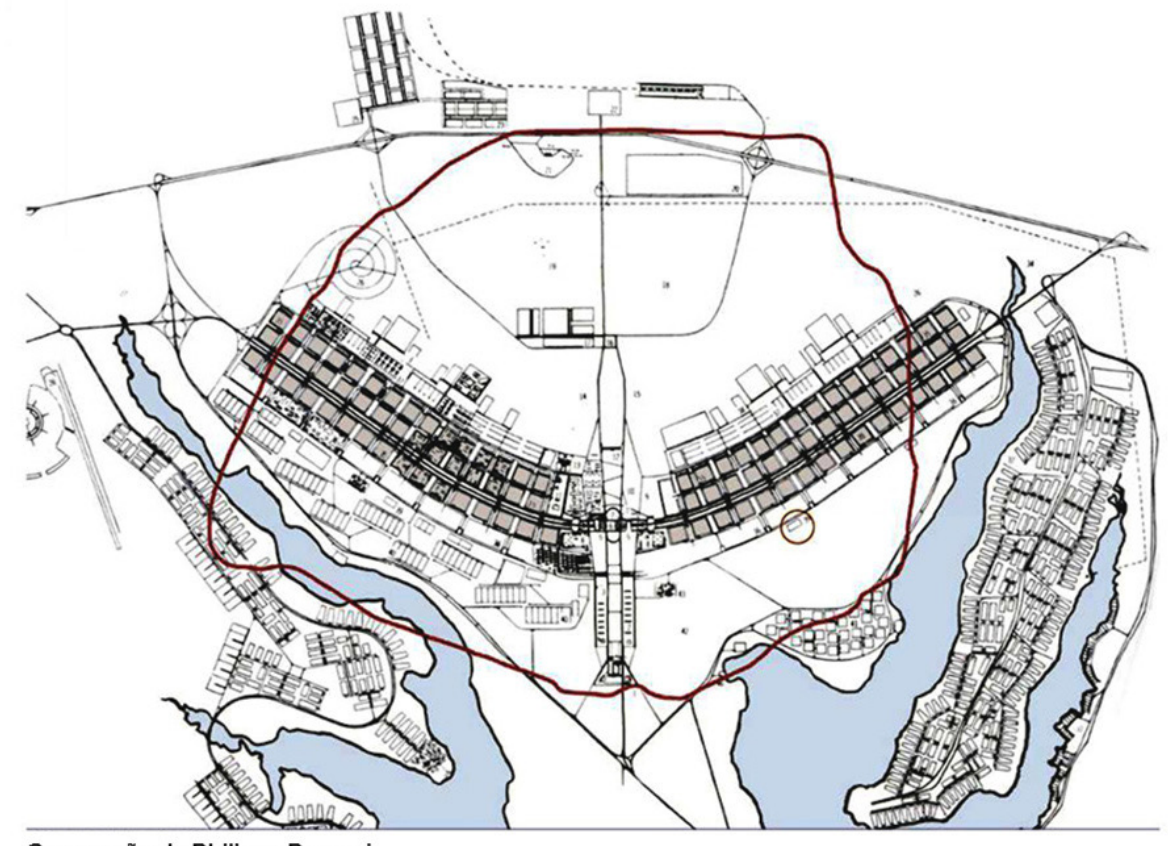

Concepção de Philippe Panerai
Figura 2 - Área delimitada pelo GDF e incluída no Patrimônio Cultural da Humanidade da UNESCO. Fonte: Decreto $n^{\circ}$ 10.829 , de 14 de outubro de 1987, GDF; disponível em: <http://www. tc.df.gov.br/sinj/Norma/15139/ Decreto_10829_14_10_1987. html>. Acesso: 18 fev. 2019.

Figura 3 - As quatro escalas do Plano Piloto. Fonte: Portaria $n^{\circ}$ 314, de 8 de outubro de 1992, IBPC; disponível em: <http:// portal.iphan.gov.br/uploads/legislacao/Portaria_n_314_de_8_de_ outubro_de_1992.pdf >. Acesso: 18 fev. 2019.

Figura 4 - Paris intramuros e - Plano Piloto. Fonte: Philippe Panerai, A Grande Paris: o nascimento da metrópole, 2010. 
permitidas, quando aprovadas pelas instâncias legalmente competentes, as propostas para novas edificações encaminhadas pelos autores de Brasília - arquitetos Lucio Costa e Oscar Niemeyer - como complementações necessárias ao Plano Piloto original...

Estes são os marcos legais que incidiam até recentemente sobre o território tombado. E qual é esse território? Trata-se de cento e treze quilômetros quadrados, abrigando cerca de $330 \mathrm{mil}$ habitantes. Área superior aos cento e três quilômetros quadrados de Paris, onde vivem mais de 2 milhões e 200 mil habitantes. Atenção, uma população quase sete vezes maior; em outros termos, uma população $700 \%$ maior do que a do Plano Piloto.
Tanto a listagem da UNESCO como as portarias federais acataram sem maior juízo crítico o desmesurado perímetro estabelecido pelo decreto distrital. Mais ainda, repetiram a mesma filosofia, uma vez que suas disposições se aplicam apenas ao Plano Piloto - em termos populares, o avião com seu Eixo Monumental e as Asas Norte e Sul ao longo do Eixo Rodoviário.

Nada ficou estabelecido para o restante da área tombada, na qual se encontram bairros de diferentes temporalidades e estágios de consolidação, como a Candangolândia, anterior ao Plano Piloto, ou o Setor Noroeste, ainda em implantação. E cuja realidade em nada corresponde àquela retratada no decreto distrital e nas portarias federais.
Figura 5 - Lucio Costa, Plano Piloto de Brasília, 1957. Fonte: Casa de Lucio Costa, disponível em: <http://www.jobim.org/lucio/ handle/2010.3/1102>. Acesso: 18 fev. 2019.

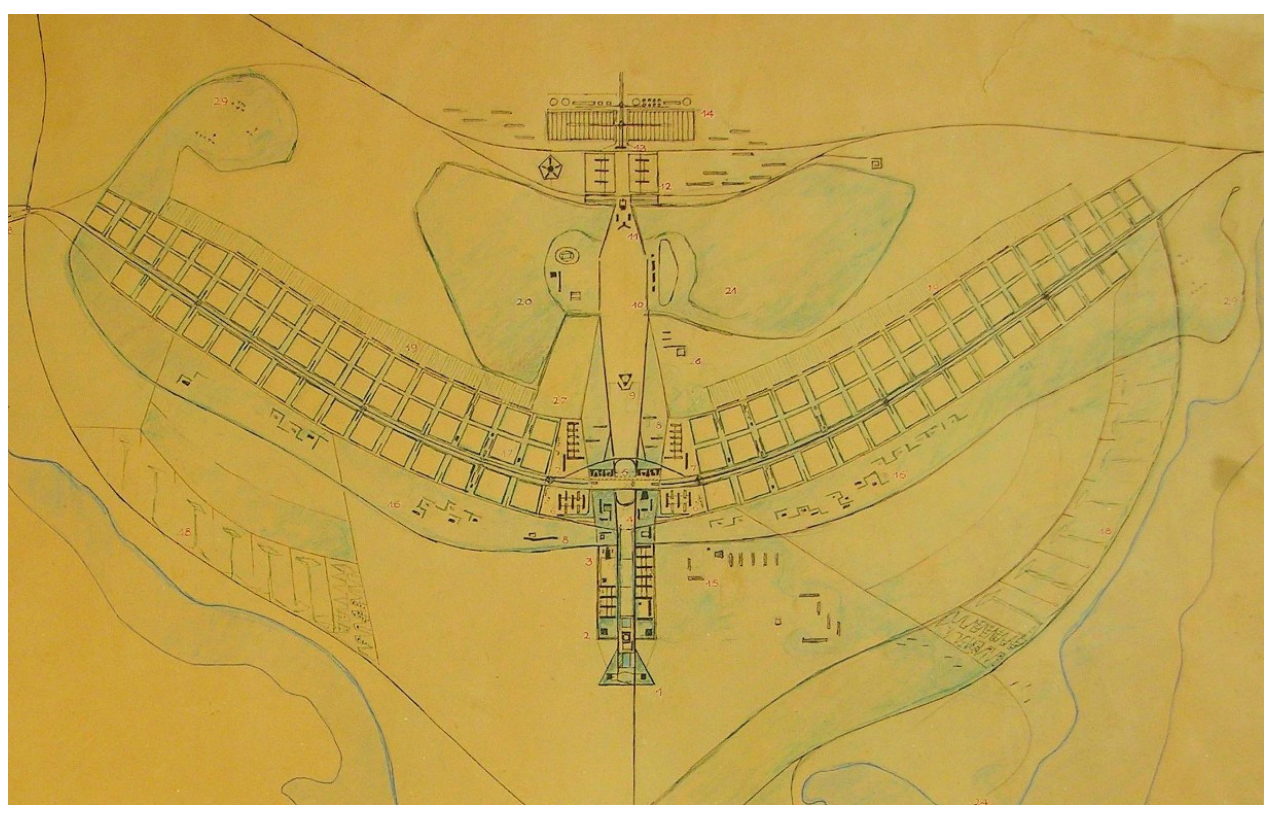




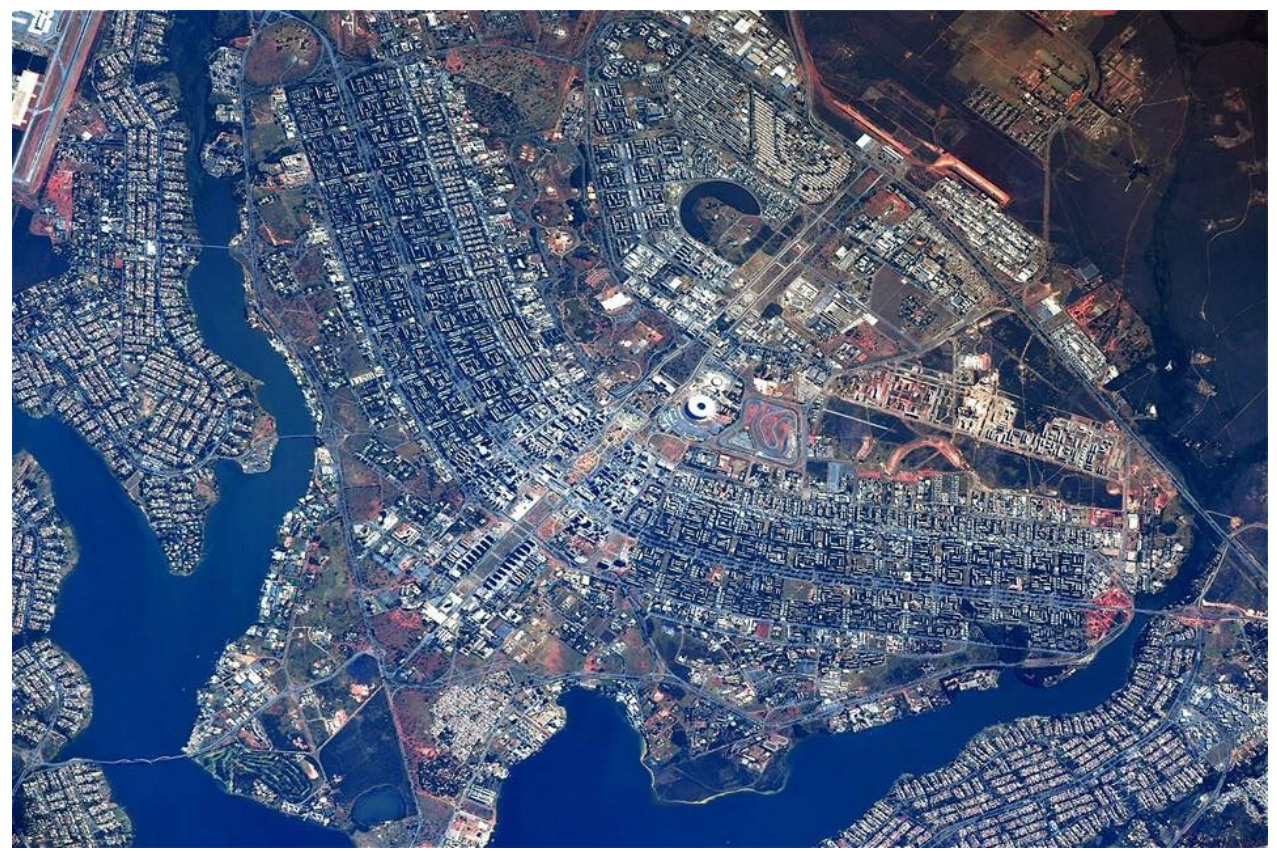

\section{TENTANDO SUPERAR O DEFICIT}

Finalmente cientes do déficit de instrumentos legais, um quarto de século depois os responsáveis pela preservação do Plano Piloto foram tomados de um furor legiferante. Em 2012, em menos de um mês foram divulgadas duas novas normas.

Pelo IPHAN foi publicada a Portaria $\mathrm{n}^{\circ} 68$, de 15 de fevereiro, afetando a envoltória do perímetro tombado. Neste caso temos uma única norma com doze artigos. Com tais doze artigos, pretendia-se garantir a visibilidade do Plano Piloto, conforme concebido por Lucio Costa, a partir da cumeada da Bacia do Paranoá e controlar usos do solo, parcelamentos e gabaritos de alturas a ser observados em um território agora sete vezes maior, ou seja, um território de mais de setecentos quilômetros quadrados. Área superior àquela não da cidade de Paris, mas da região metropolitana de Paris.

Pela Secretaria de Desenvolvimento Urbano e Habitação (SEDHAB) foi apresentada em 12 de março uma minuta de Projeto de Lei Complementar do Plano de Preservação do Conjunto Urbanístico de Brasília (PPCUB). Norma bem mais complexa que as anteriores, propunha cento e setenta e oito artigos. Uma de suas Planilhas de Parâmetros Urbanísticos chegava a prever a divisão de um trecho da cidade em onze áreas de preservação, cada uma delas, por sua vez, subdivididas em várias unidades de proteção. O que estava sendo proposto de fato era o esquartejamento definitivo do tecido urbano, já por si excessivamente setorizado. A sua única qualidade,
Figura 6 - Foto do astronauta russo Sergey Ryazanskiy, tirada da Estação Espacial Internacional, 2017. Fonte: Ricardo Faria, Astronauta russo fotografa Brasília, 2017. 
Figura 7 - Envoltória do perímetro tombado. Fonte: Portaria $\mathrm{n}^{\circ}$ 68, de 15 de fevereiro de 2012, IPHAN; disponível em: <http:// portal.iphan.gov.br/uploads/ legislacao/Portaria_n_68_de_15_ de_fevereiro_de_201>. Acesso: 18 fev. 2019.

Figura 8 - Efeitos da Portaria $n^{\circ}$ 68/2012, IPHAN. Fonte: Helena Mader, Proteção extra ao tombamento, 2012.

Figura 9 - Projeto de Lei Complementar do Plano de Preservação do Conjunto Urbanístico de Brasília (PPCUB), 12 de março de 2012, GDF. Fonte: Disponível em: <http:// www.segeth.df.gov.br/wp-conteudo/uploads/2017/11/anexo2e3-1. pdff. Acesso: 18 fev. 2019.
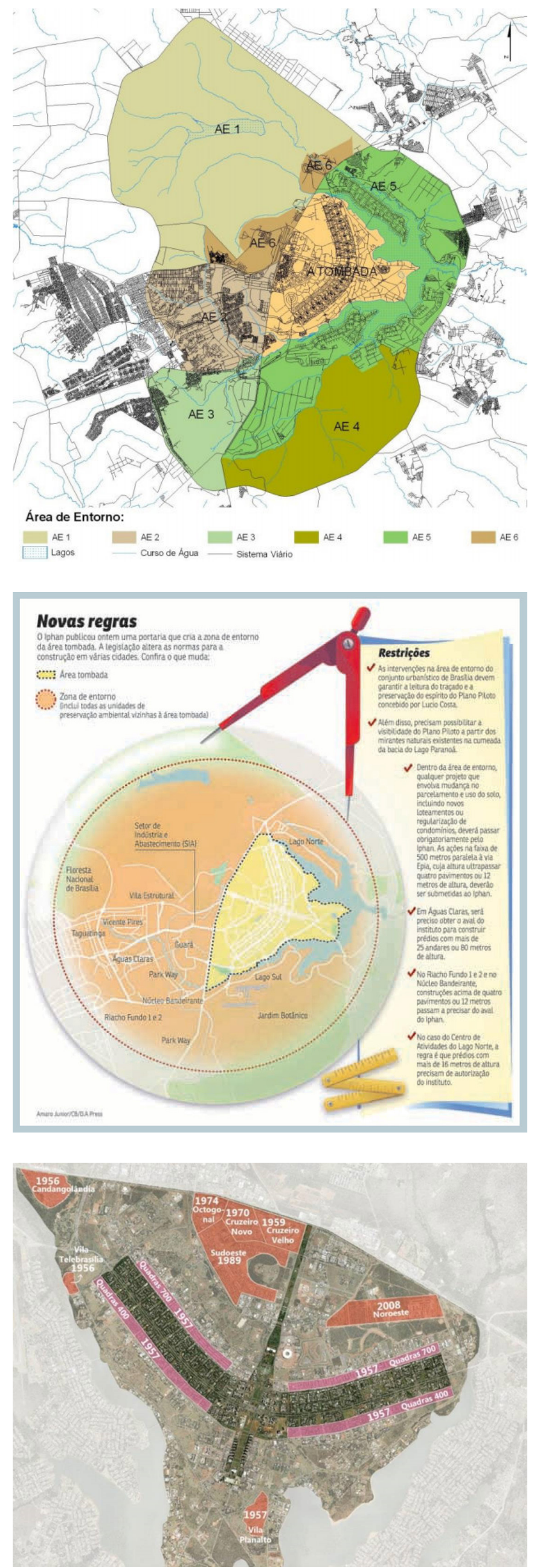
o reconhecimento da complexidade de morfologias nele contidas.

Em resumo, enquanto a norma distrital preconizava a preservação do Plano Piloto e adjacências pensada e gerida sem considerar suas relações com o todo da aglomeração, a norma federal nos conduzia de volta aos primórdios de Brasília, reiterando o cordão sanitário que começou a ser imposto à cidade ain$\mathrm{da}$ antes de sua inauguração, quando da criação de Taguatinga em 1958. Resta o consolo que a proposta distrital continua sendo debatida e a portaria federal nunca teve condições de ser implementada, ficou esquecida...

\section{O EXEMPLO DE SÃO LUÍS}

Fica evidente que as dimensões exageradas da área tombada de Brasília, aliada às variações temporais e morfológicas nela contida, tornaram-se um problema de legislação patrimonial de difícil solução e constituem entraves na sua gestão urbana. A prática, quando da preservação urbana, aconselha a definição de perímetros contendo conjuntos menos extensos e mais homogêneos.

Tomemos o exemplo de São Luís do Maranhão. A proteção de seu centro histórico está contemplada por legislações federais, reforçada por tombamento estadual e ampliada por ações municipais de planejamento. Assim como Brasília, a cidade está inscrita no Patrimônio Cultural da Humanidade da UNESCO. Mas ao contrário do que ocorre em Brasília, onde a área tombada é a mesma para as esferas distrital, federal e internacional, no caso de São Luís a cada um desses níveis de defesa corresponde um perímetro próprio, o que permite uma gradação nas ações preservacionistas. De modo que a área maior é a municipal, a qual contem as demais.
Figura 10 - Centro histórico de São Luís. Fonte: Disponível em: <http://portal.iphan.gov.br/ pagina/detalhes/34>. Acesso: 15 fev. 2019.

Figura 11 - Zonas e Limites de Proteção do Centro de São Luís. onte: José A. Viana Lopes (org.), São Luís, Ilha do Maranhão e Alcântara, 2008.
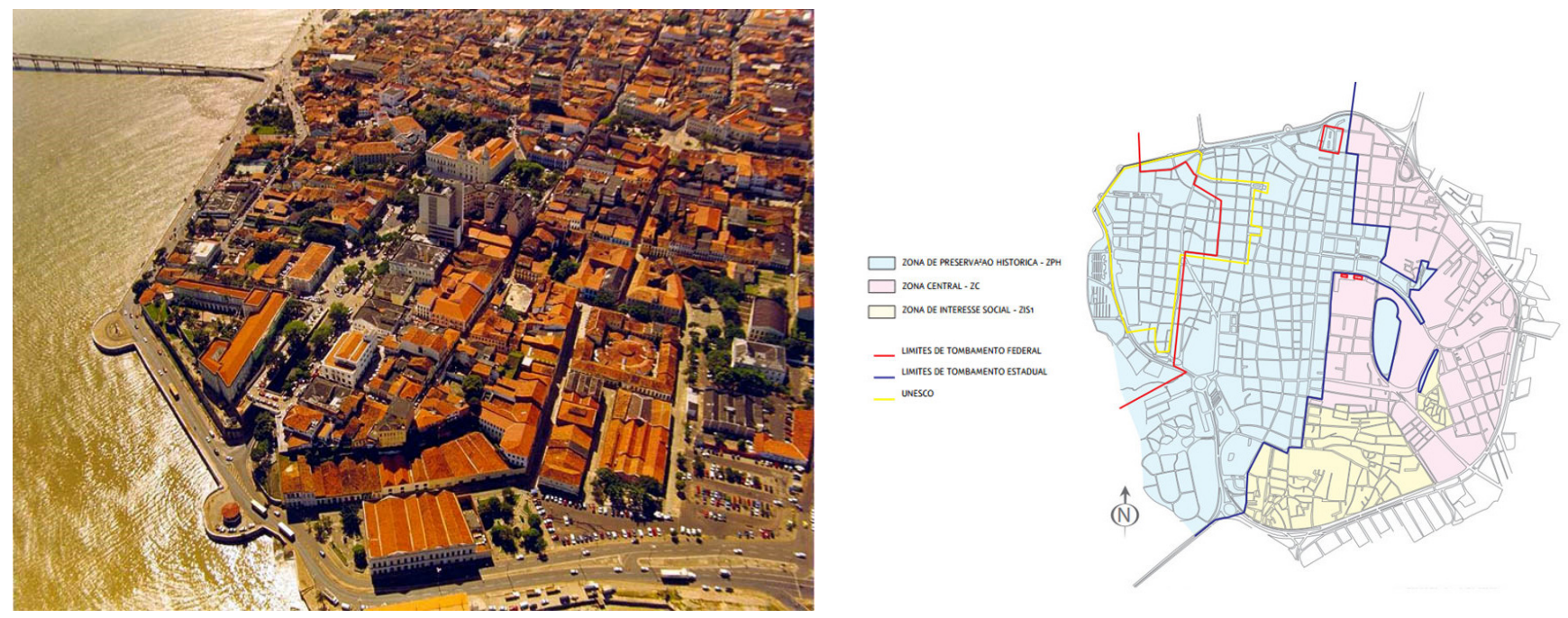
O atual perímetro federal foi estabelecido pelo IPHAN em 1974 como Conjunto Arquitetônico e Paisagístico da Cidade de São Luís (Livro do Tombo Arqueológico, Etnográfico e Paisagístico, Inscrição $n^{\circ}$ 64; Livro do Tombo das Belas-Artes, Inscrição n ${ }^{\circ}$ 513) e abarca sessenta hectares. Seguiu-se o tombamento estadual em 1986 (Decreto no 10.089), incluindo a mesma área acrescida de seu entorno, em um total de cento e sessenta hectares. Em 1992, pela Prefeitura Municipal foi aprovado o Plano Diretor (Lei n ${ }^{\circ}$ 3.252) e o Plano de Zoneamento, Parcelamento, Uso e Ocupação do Solo Urbano (Lei n 3.253) estabelecendo uma área de aproximadamente duzentos e oitenta hectares, a qual está dividida em Zona de Preservação Histórica - incluindo as anteriores -, Zona Central e Zona de Interesse Social. Curiosamente, a área listada pela UNESCO em 1997 é algo maior do que a federal.

Mesmo tal diferenciação de graus de proteção estabelecida para São Luís, que permite maior discernimento nas ações de preservação e revitalização de diferentes órgãos públicos, afeta um território mínimo quando comparado aos mais de dez mil hectares definidos em Brasília.

\section{UM NOVO MARCO LEGAL}

Nem tudo está perdido... Em 2016, foi aprovada pelo IPHAN uma regra mais realista e eficiente, a Portaria no 166 , de 11 de maio. Apresentada, oficialmente, como Complementação e Detalhamento da Portaria no 314/1992, na verdade trata-se de uma tentativa de superar as suas dificuldades de aplicação, em especial aquelas sobrevindas de um território excessivamente dilatado e da inclusão de bairros que nem deveriam estar sujeitos a iguais medidas de proteção, alguns não completamente edificados até hoje. Em vigor no seu todo, recebeu alterações apenas pontuais pela Portaria no 421 , de 31 de outubro de 2018.

A promissora novidade foi o estabelecimento justamente da gradação que faltava para orientar as ações de preservação, agora garantida por meio da definição de duas macrozonas. A Macrozona $\mathrm{B}$ funciona, na prática, como transição e amortecimento para a Macrozona $\mathrm{A}$, a qual contém o bem sob proteção maior. Permitindo, assim, que os controles mais rígidos fiquem concentrados naquela porção do Plano Piloto real que mais se aproxima do Plano Piloto originalmente idealizado.

\section{PARA ALÉM DA GESTÃO, A CONCEPÇÃO URBANÍSTICA}

O tombamento de Brasília tem uma outra face, uma face não muito ensolarada, em consequência da simultânea preservação de uma outra ordem de problemas, aqueles que já existiam na cidade. E, por consequência, vindo o tombamento, a impossibilidade de sequer se pensar em soluções para remediá-los. Há um bloqueio mental, uma verdadeira cen- 


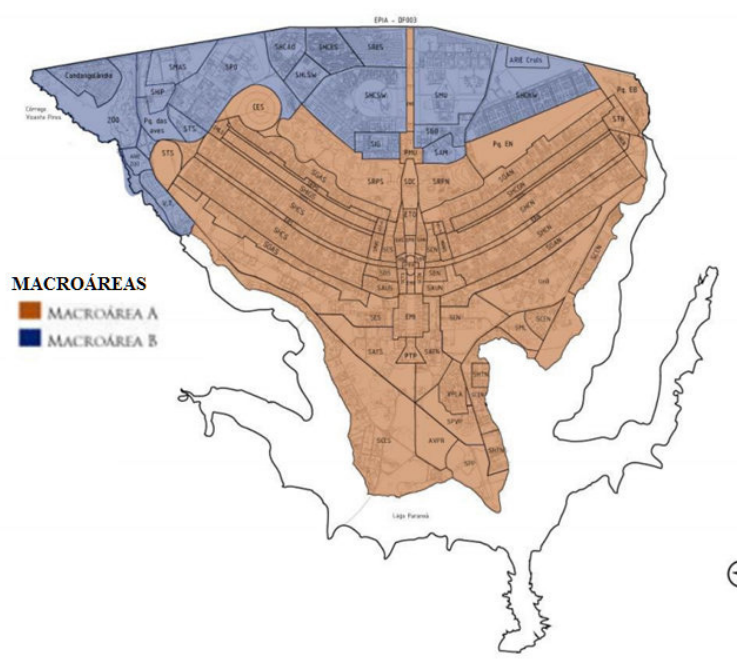

(7)

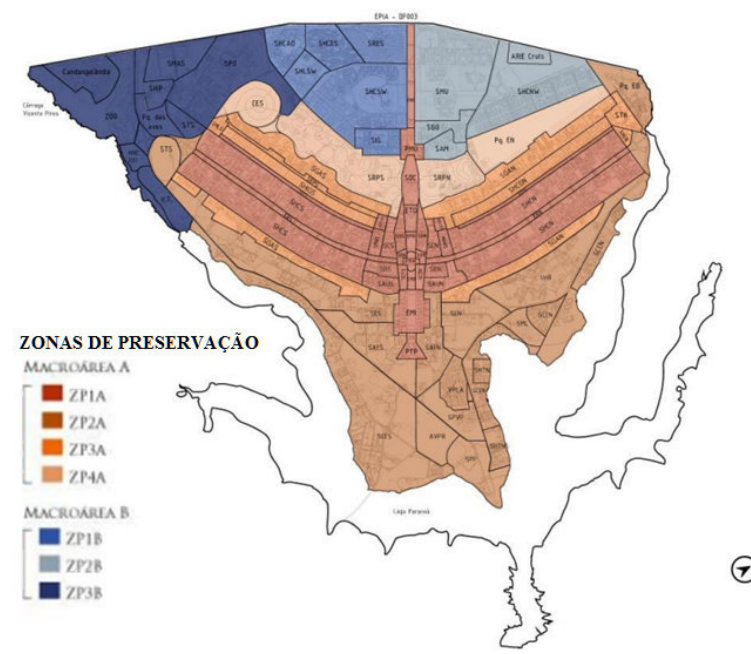

Figura 12 - Macroáreas de Proteção A e B. Fonte: Portaria n ${ }_{166}$, de 11 de maio de 2016, com alterações introduzidas pela Portaria $n^{\circ} 421$, de 31 de outubro de 2018 , IPHAN; disponível em: <http:// portal.iphan.gov.br/uploads/legislacao/portaria_166_consolidada_2018_com_mapas>. Acesso: 18 fev. 2019.

Figura 13 - Macroáreas A e B e respectivas Zonas de Preservação. Fonte: Portaria $n^{\circ} 166$, de 11 de maio de 2016 , com alterações introduzidas pela Portaria $n^{\circ} 421$, de 31 de outubro de 2018, IPHAN; disponível em: <http://portal. iphan.gov.br/uploads/legislacao/ portaria_166_consolidada_2018_ com_mapas $>$. Acesso em $18 \mathrm{fev}$. 2019. Acesso: em 18 fev. 2019.

Figura 14 - Sobreposição do croqui de Lucio Costa (1957) e da área tombada. Fonte: Portaria $\mathrm{n}^{\circ}{ }_{166}$, de 11 de maio de 2016 , com alterações introduzidas pela Portaria $n^{\circ} 421$, de 31 de outubro de 2018, IPHAN; disponível em: <http://portal.iphan.gov.br/ uploads/legislacao/portaria_166_ consolidada_2018_com_mapas>. Acesso: 18 fev. 2019. 


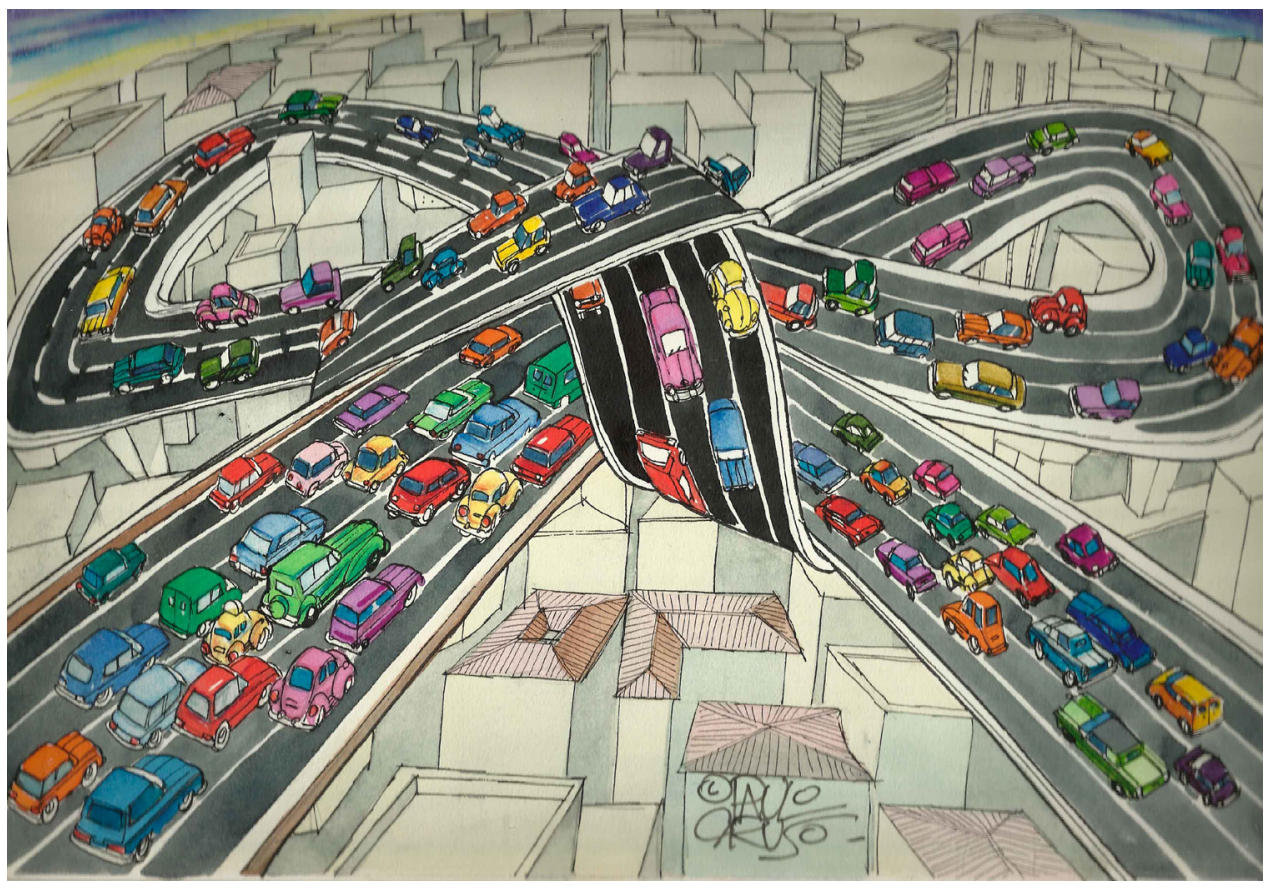

sura a qualquer exercício de proposição urbanística ou arquitetônica para o Plano Piloto. Até um despretensioso comentário de que nem tudo é perfeito na sua concepção é tratado como heresia.

Por outro lado, fala-se muito em descaracterização do Plano Piloto, em puxadinhos e esticadinhos. Descaracterização é coisa bem mais séria. Puxadinhos e esticadinhos - ou seja, invasões pontuais de terrenos públicos e desrespeitos improvisados a gabaritos - são meras infrações, detalhes quase que cosméticos quando se considera a magnitude do projeto de Lucio Costa. Afinal, o seu Plano Piloto está tatuado no chão, não é facilmente riscado do mapa.

Essa outra ordem de problemas não advém de falhas pessoais, de idiossincra- sias de seu urbanista. Resulta dos ideais urbanísticos correntes à época em que Brasília foi concebida. Dentre eles, o mais preocupante é o excessivo rodoviarismo que caracteriza o Plano Piloto.

Rodoviarismo esse fruto do afã - bem típico do urbanismo funcionalista de então - de se erigir cidades com cara de tudo, menos com a cara de cidades tradicionais, com suas ruas, quarteirões e lotes. Com o argumento de que assim, funcionais, seriam cidades também mais adequadas ao automóvel. Como se a cidade tradicional já não suportasse a circulação de meios de transporte bem mais perturbadores: os meios de transporte a tração animal. Imaginem as cidades atuais congestionadas não com motos, mas com cavalos; não com automóveis, 
mas com carruagens; não com vans, mas com coches; não com ônibus, mas com diligências; não com pick-ups, mas com carroças; não com caminhões, porém com carros de boi...

Agravando a situação, imprudentemente o DNA rodoviarista não ficou restrito ao Plano Piloto e continua a imperar soberano no Distrito Federal, alastrado por todo o seu território. $\mathrm{O}$ sistema viário da metrópole brasiliense é pensado privilegiando o automóvel e facilitando altas velocidades. Nada menos surpreendente, nada mais compreensível que o principal sonho de consumo de seus habitantes seja adquirir um carro em uma cidade que não oferece melhores opções de transporte.

Porém, no mesmo fôlego em que é facilitado o bem-bom dos motoristas, virou moda reclamar que Brasília tem automóveis de mais. Enquanto apenas as mansões dos beaux quartiers - como o Lago Sul e o Lago Norte - podiam arcar com dois, três ou quatro carros em suas garagens, tudo bem... Agora que moradores das cidades satélites - a manicure do Gama, o eletricista de São Sebastião e a diarista de Águas Limpas - conseguiram comprar seus fusquinhas, todos saem reclamando que Brasília tem automóveis de mais!! Já o pessoal de Santa Luzia, na Estrutural, e do Sol Nascente, em Ceilândia, continuam a pé, isolados das benesses da Capital Federal dada a carência de meios de transportes módicos.

Esta não é uma defesa do império do automóvel, pelo contrário. Apenas a constatação de que em uma cidade pensada na lógica do rodoviarismo, o porte mais eficiente do ponto de vista do interesse de cada indivíduo, mesmo quando se considera o seu alto custo de compra, impostos e manutenção e aquele dos combustíveis. Ou será que é por pura insensatez que os brasilienses se dão ao luxo de manter o mais alto número de carros per capita do país? Algo como duas pessoas por veículo, contra as quatro da média nacional.

\section{CRUZAMENTOS E SEMÁFOROS}

Para exemplificar como se perpetua o DNA rodoviarista, considere-se o trevo rodoviário recentemente concluído em plena área tombada, em local nobre ou prime real estate, como se diz no jargão imobiliário. Foi construído para articular o Setor de Autarquias Sul e a Via L2 Sul com a Via L4, para tanto ocupando uma imensa gleba, capaz de abrigar toda uma superquadra. E isso para quê? Para evitar um simples cruzamento, facilmente administrável com um bom sistema de semáforos sincronizados. Deteriora-se um lindo terreno, esburaca-se ainda mais o chão, esfarrapa-se ainda mais o tecido urbano, dificulta-se ainda mais a vida dos pedestres, gasta-se uma barbaridade de dinheiro público, para quê? Para facilitar altas velocidades para os automóveis, para facilitar a vida dos motoristas.

Obras como essa são feitas porque no arsenal de preconceitos urbanísticos da década de 1950 constava que cruzamentos 
Figura 16 - Trevo rodoviário, L2 Sul. Fonte: Google Earth, 2018.

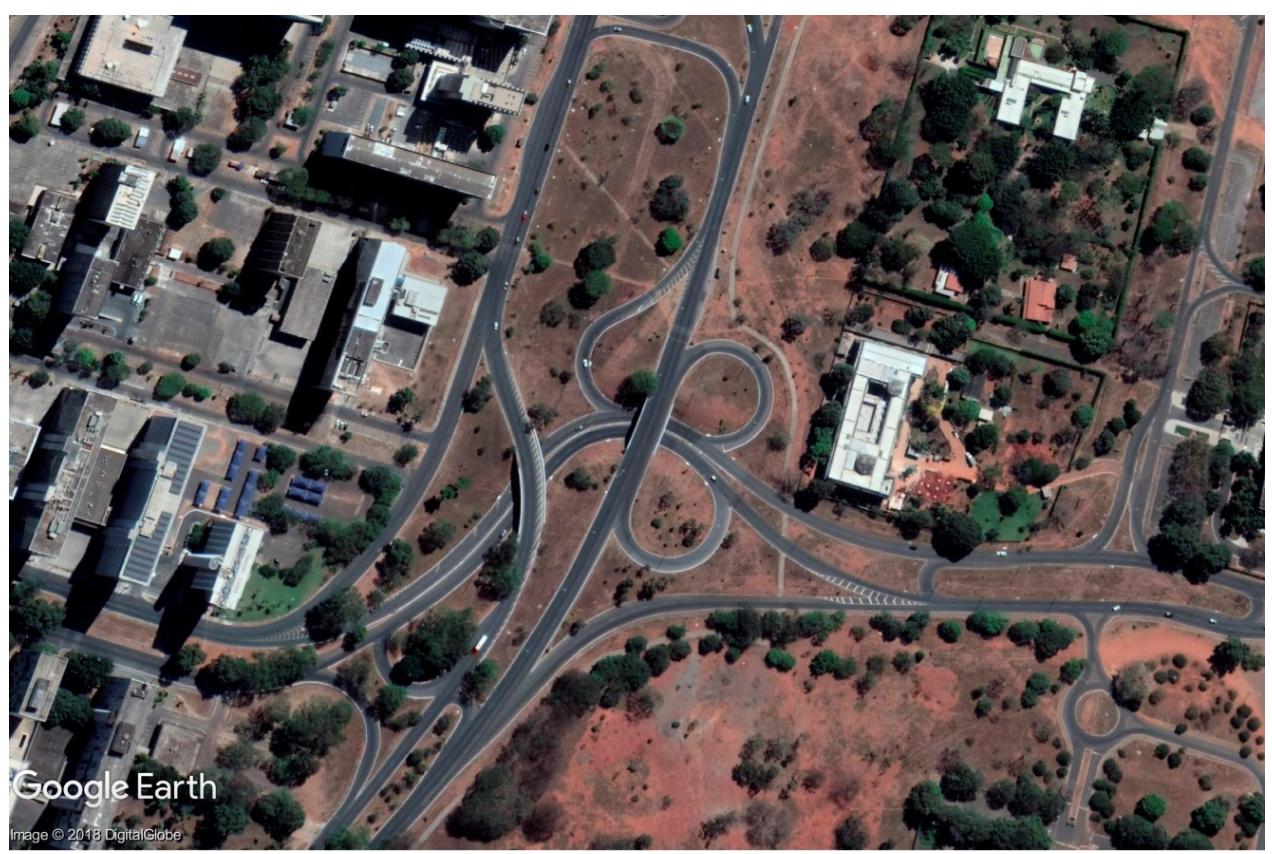

e semáforos criam congestionamentos. Brasília está aí para demonstrar a falácia do argumento. Temos poucos cruzamentos e poucos semáforos e temos muitos congestionamentos. E boa parte desses congestionamentos é causada justamente pela falta de cruzamentos e semáforos!

Fato é que o próprio Lucio Costa não se opunha a semáforos, conforme esclareceu em entrevista a Omar Abudd, publicada em novembro 1984 no Jornal do Brasil. Ao dar sua opinião quanto à adoção desse equipamento no Plano Piloto, esclarece:

Há certa confusão. O Plano estabeleceu dois sistemas viários; um, principal, fluente, dos eixos rodoviários, e outro lateral, que eu chamava de vias de serviço... E no Plano, está dito que este segundo era para ser sinalizado de qualquer maneira. De modo que a sinalização não é uma inovação. E mesmo na área fluente, rodoviária, em que eu quis aplicar um pouco dessa técnica rodoviária à área urbana..., eu pretendi que essa via rodoviária chegasse no coração da cidade, na plataforma. E aí o sujeito está em casa, está dentro da cidade e não fora. De qualquer maneira, eu quero assinalar que mesmo nessa área de tráfego fluente, era fundamental ter sim, porque, senão, o pedestre jamais atravessaria, não haveria quebra de ritmo do tráfego.

\section{O EIXÃO}

O Eixo Rodoviário Residencial do Plano Piloto, o conhecido Eixão, é um triste exemplo das consequências do rodovia- 
rismo. Todos concordam que é uma via perigosa, o número de acidentes fatais é extremamente alto. E quem morre é quase sempre um pedestre. Só que o diagnóstico da situação põe a culpa nele, no pedestre; ele é que é o culpado por morrer na contramão da urbanidade ao se recusar a utilizar insalubres passagens subterrâneas.

Aí são buscadas alternativas atreladas ao próprio rodoviarismo. Por que não reformar as passagens subterrâneas? Afinal pedestre não têm grande relevância para o rodoviarismo. Ou passarelas elevadas, daquelas que, além de serem íngremes, de oferecerem más condições de acessibilidade, de quebra ainda enfeiam a paisagem?

Essas fórmulas miraculosas não são malvistas - pelos motoristas, é claro. Já alguns urbanistas, entre os quais me coloco, são considerados terroristas que querem destruir o Plano Piloto por preconizar canteiros centrais ao longo do Eixão, complementados por faixas e semáforos para pedestres. Mudando o paradigma, uma solução que ao rodoviarismo contrapõe a diminuição das velocidades no trânsito em nada prejudica a proposta de Lucio Costa. Pelo contrário; a humanização do Eixão poderá contribuir para a preservação da escala residencial das suas superquadras. Como bem demonstram algumas simulações feitas pela arquiteta Eduarda Aun segundo concepção do professor Frederico de Holanda.

Com seus cinco quilômetros de extensão, a orla de Santos é considerada pelo Guinness Book o maior jardim do mundo ao longo de uma praia. Pode-se imaginar o jardim no qual seria possível transformar os treze quilômetros e meio do Eixão?

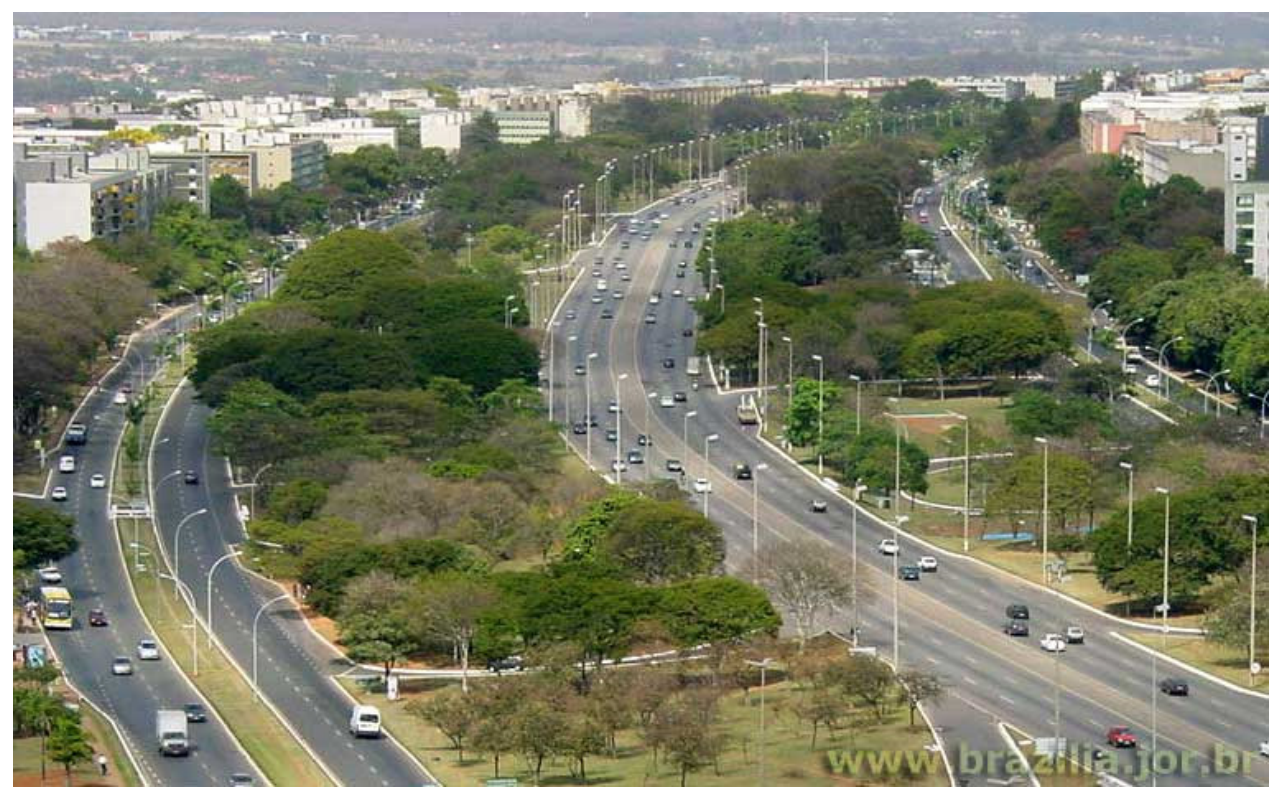

Figura 17 - Eixo Rodoviário Residencial, Plano Piloto. Fonte: Disponível em: <http://doc.brazilia.jor.br/Vias/Eixo-Rodoviario. shtml>. Acesso em 21 fev. 2019. 
Figura 18 - Passagem subterrânea, Eixo W Sul; foto de Ana Rayssa. Fonte: Walder Galvão e Jéssica Eufrásio, Passarelas do medo, 2019.

Figura 19 - Passagem subterrânea, Eixo W. Foto Wallace Martins. Fonte: Walder Galvão e Jéssica Eufrásio, J. Passarelas do medo, 2019.

Figura 20 - Proposta para o Eixão, Frederico de Holanda e Eduarda Aun, 2017. Fonte: Frederico de Holanda.

Figura 21 - Proposta para o Eixão, Frederico de Holanda e Eduarda Aun, 2017. Fonte: Frederico de Holanda.

Figura 22 - Jardins da orla de Santos. Disponível em: <https://br.pinterest.com/pin/540291286540835433/?lp=true >. Acesso em 21 fev. 2019.
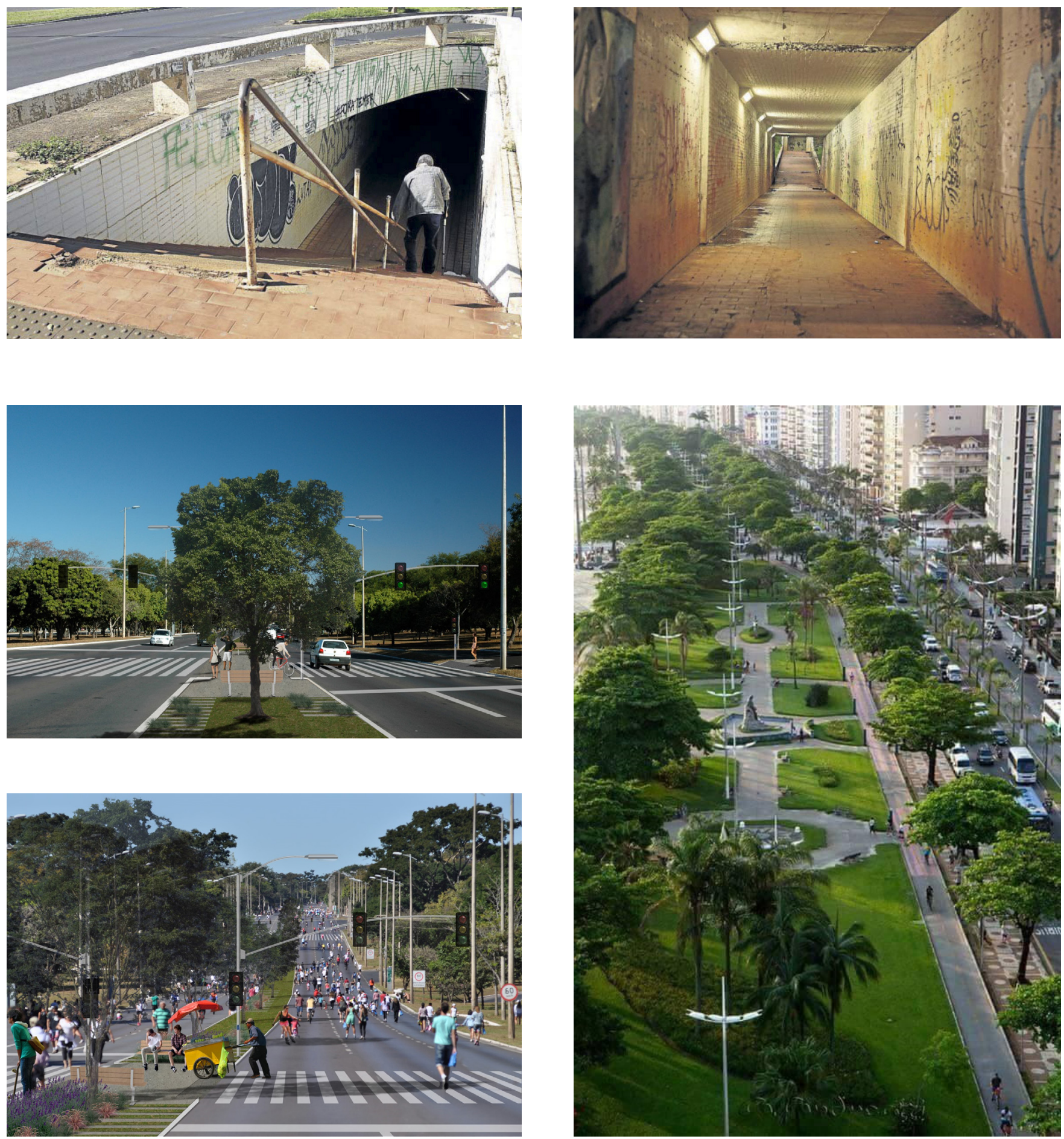


\section{AMBIENTE NATURAL E ARTIFICIAL}

$\mathrm{Na}$ discussão da gestão patrimonial de Brasília, falta considerar uma questão que deveria nos preocupar, aquela do meio ambiente. Meio ambiente em sentido abrangente - natural e artificial. Brasília já é uma das maiores cidades do país e a preservação do seu Plano Piloto continua a ser pensada sem relação, seja com o todo da aglomeração, seja como integrante de tal meio ambiente.

Surpreendentemente, $42 \%$ do Distrito Federal estão protegidos por algum tipo de norma. Estações ecológicas, reservas biológicas, parques públicos, paisagens de relevante interesse ecológico e assim por diante. Só a Biosfera do Cerrado engloba $40 \%$ desse território. E mais, essas áreas não são tão naturais assim; nelas há vestígios da ocupação humana na região. Brasília não começou em 1956 ou em 1960. Poucos sabem, mas há no Distrito Federal remanescentes de pelo menos uma dúzia de sedes de fazendas erigidas do século dezoito em diante.

No mais das vezes são acirradas as polêmicas sobre questões menores como os puxadinhos \& Cia. - e perdido de vista o panorama maior da administração de uma metrópole com cerca de 4 milhões de habitantes, a qual tem entre as suas características um centro objeto de legítimas ações de proteção.
Inegavelmente, a metrópole tem uma forte relação de dependência com o Plano Piloto. Porém o Plano Piloto não existe no vácuo, ele é parte da metrópole, é dela igualmente dependente e só poderá ter sua carga simbólica preservada caso se fortaleçam e se estreitem os elos entre esse core de alto significado urbanístico e arquitetônico e a aglomeração maior. Não com o objetivo de se incensar ainda mais seu valor - já suficientemente reconhecido -, mas no fito de estender suas qualidades para toda a metrópole.

As ações de preservação urbanística e arquitetônica têm que estar articuladas àquelas de proteção de reservas ambientais e de nascentes, fundos de vale e matas ciliares. Para a necessária melhoria da região metropolitana deve ser pensada uma revisão e mesmo ampliação do sistema viário de conjunto, não por vias expressas, porém pela abertura de ruas e avenidas que garantam a maior e imprescindível coesão do disperso tecido urbano. Apenas com políticas dessa ordem será possível desviar as pressões imobiliárias crescentes que se exercem sobre a área tombada para os demais bairros da cidade, estes sim necessitando urgente requalificação. Quanto mais aproximarmos o Plano Piloto dessa outra Brasília, quanto mais elevada a urbanidade dessa outra Brasília, mais garantida estará a sua salvaguarda. 
Figura 23 - Paulo Caruso, $\mathrm{O}$

destino de Brasília. Fonte: acervo

da autora.

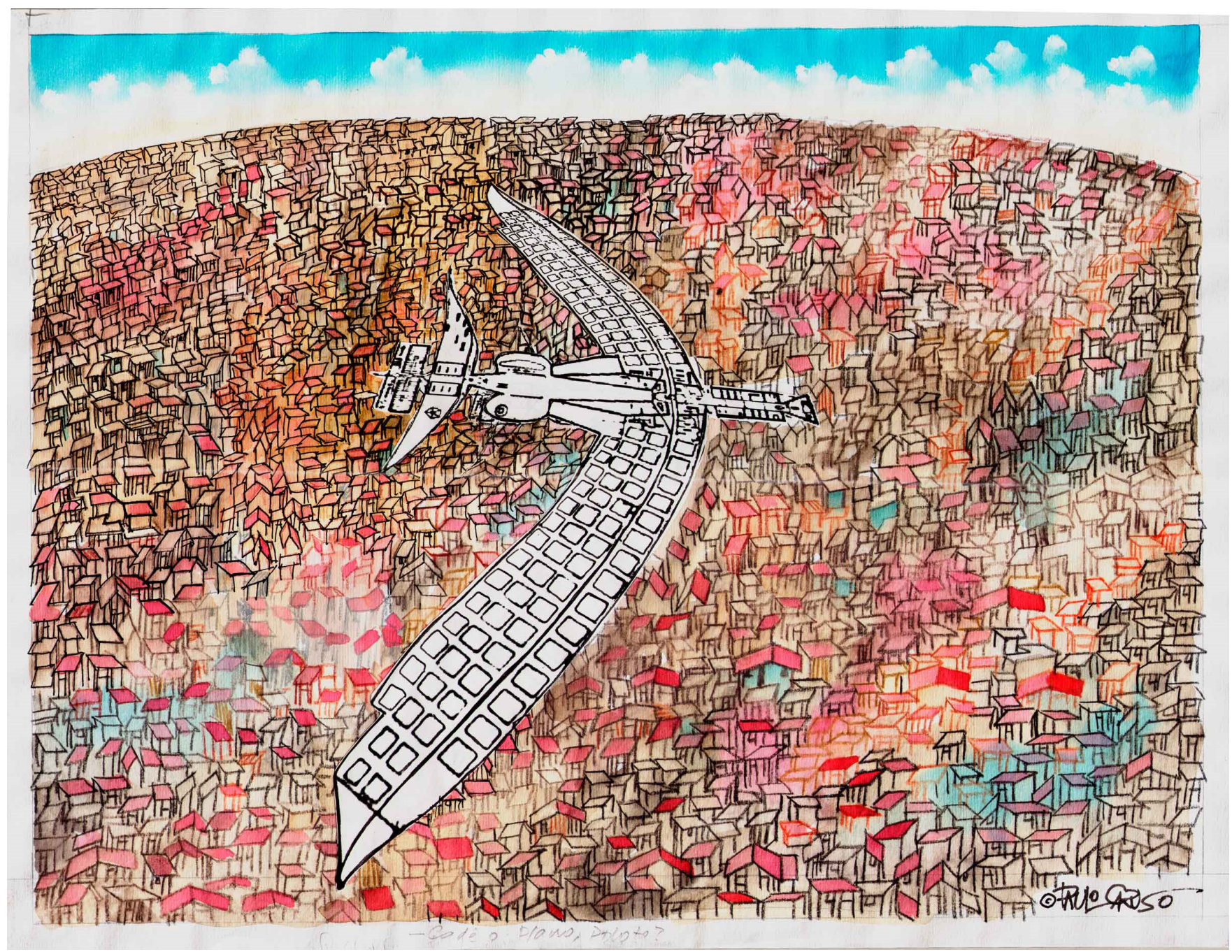




\section{REFERÊNCIAS BIBLIOGÁFICAS}

ANJOS, Rafael S. dos. Expansão urbana no Distrito Federal e entorno imediato (19641990). Dissertação (Mestrado em Arquitetura e Urbanismo), FAU/UnB, Brasília, 1991.

BRITO, J. A. De Plano Piloto a metrópole: a mancha urbana de Brasília. Brasília: SINDUSCON, 2010.

COSTA, L. Brasília revisitada 1985/1987. Projeto, no 100, p. 115-22, jun. 1987. . Memória Descritiva do Plano Piloto, 1957. In: COSTA, L. Registro de uma vivência. São Paulo: Empresa das Artes; Brasília: EDUnB, 1995, p. 283-97.

DECRETO no 10.829/1987, GDF. Disponível em: <http://www.tc.df.gov.br/sinj/Norma/15139/Decreto_10829_14_10_1987.html>.Acesso em 18 fev. 2019.

FARIA, R. Astronauta russo fotografa Brasília. Correio Braziliense, p. 20, 1 set. 2017.

FICHER, S. Paradigmas urbanísticos de Brasília. Revista da Biblioteca Mário de Andrade, São Paulo, nº 65, p. 93-121, 2010.

et al. Brasília, causos e casuísmos patrimoniais. In: FERNANDES, E.; ALFONSIN, B. (orgs.). Revisitando o instituto do tombamento. Belo Horizonte: Fórum, 2010. p. 357-74.

et al. Brasilia: la historia de un planeamiento. In: RODRÍGUEZ I VILLAESCUSA, E.; FIGUEIRA, C. A. (orgs.). Brasilia 1956 > 2006. Lleida: Milenio, 2006. p. 55-97. GALVÃO, W.; EUFRÁSIO, J. Passarelas do medo. Correio Braziliense, p. 21, 10 fev. 2019.

IBGE, Coordenação de Geografia. Áreas urbanizadas do Brasil: 2015. Rio de Janeiro: IBGE, 2017.

MADER, Helena. Proteção extra ao tombamento. Correio Braziliense, p. 25, 23 fev. 2012.

PANERAI, P. A Grande Paris: o nascimento da metrópole, três momentos em uma longa história. In: SEGRE, R. et al. $8^{\circ}$ Docomomo Brasil: arquitetura+arte+cidade. Rio de Janeiro: PROURB, 2010. p. 352-63.

Paris métropole: formes et échelles du Grand-Paris. Paris: Éditions de La Villette, 2008.

PAVIANI, A. et al (orgs.). Brasília 50 anos: da capital a metrópole. Brasília: EDUnB, 2010.

PORTARIA IBPC no 314, de 8 de outubro de 1992. Disponível em: < http://portal.iphan.gov. br/uploads/legislacao/Portaria n 314 de 8 de outubro de 1992.pdf $>$. Acesso em 18 fev. 2019.

PORTARIA IPHAN no 68, de 15 de fevereiro de 2012. Disponível em: < http://portal.iphan. gov.br/uploads/legislacao/Portaria n 68 de 15 de fevereiro de 201>. Acesso em 18 fev. 2019.

PORTARIA IPHAN no 166, de 11 de maio de 2016, com alterações introduzidas pela Portaria $\mathrm{n}^{\circ}$ 421, de 31 de outubro de 2018. Disponível em: <http://portal.iphan.gov.br/uploads/legislacao/portaria 166 consolidada 2018 com mapas >. Acesso em 18 fev. 2019. 
PROJETO DE LEI COMPLEMENTAR. Plano de Preservação do Conjunto Urbanístico de Brasília (PPCUB), 12 de março de 2012, GDF. Disponível em: <http://www.segeth. df.gov.br/wp-conteudo/uploads/2017/11/anexo2e3-1.pdf >. Acesso em 18 fev. 2019.

REIS, C. M. Gestão de centros históricos no Brasil: cidades Patrimônio Mundial, os casos de Brasília e São Luiz. Tese (Doutorado em Arquitetura e Urbanismo), FAU/UnB, Brasília, 2011.

RIBEIRO, G. L. O capital da esperança: 1956-61. Brasília: EDUnB, 2008.

Sylvia Ficher - Professora Titular da FAU/UnB. Arquiteta (FAU/USP), Mestre em Preservação Histórica (Columbia University, Nova York), Doutora em História Social (FFLCH/USP), com Pós-doutorado em Sociologia (École des Hautes Études en Sciences Sociales, Paris).sficher@unb.br. 